\title{
PENGARUH KOMPETENSI DAN MOTIVASI KERJA TERHADAP KINERJA KARYAWAN DI PD BPR BANK BULELENG 45
}

\author{
Ni Kadek Ayu Dwiyanti ${ }^{1}$, Komang Krisna Heryanda ${ }^{2}$, Gede Putu Agus Jana \\ Susila ${ }^{3}$ \\ ${ }^{123}$ Jurusan Manajemen, Fakultas Ekonomi, Universitas Pendidikan Ganesha Singaraja \\ e-mail: ayudwiyanti@gmail.com, krisna.heryanda@undiksha.ac.id, janos undiksha@yahoo.com
}

\begin{abstract}
Abstrak
Penelitian ini bertujuan untuk memperoleh temuan eksplanatif yang teruji tentang pengaruh (1) kompetensi dan motivasi kerja terhadap kinerja karyawan, (2) kompetensi terhadap motivasi kerja karyawan, (3) kompetensi terhadap kinerja karyawan, (4) motivasi kerja terhadap kinerja karyawan pada PD. BPR Bank Buleleng 45. Desain penelitian dalam penelitian ini adalah kuantitatif kausal. Subjek dalam penelitian ini adalah seluruh karyawan pada PD BPR Bank Buleleng 45 dan objeknya adalah kompetensi, motivasi kerja, dan kinerja karyawan. Populasi penelitian ini berjumlah 51 karyawan semuanya dijadikan unit pengamatan, sehingga penelitian ini termasuk penelitian populasi. Data dikumpulkan dengan kuesioner, pencatatan dokumen, wawancara langsung dan analisis data menggunakan analisis jalur. Hasil yang diperoleh dalam penelitian ini menunjukkan bahwa (1) Kompetensi dan motivasi kerja berpengaruh positif terhadap kinerja karyawan dengan. (2) Kompetensi berpengaruh positif terhadap motivasi kerja. (3) Kompetensi berpengaruh positif terhadap kinerja karyawan. (4) Motivasi kerja berpengaruh positif terhadap kinerja karyawan karyawan pada PD BPR Bank Buleleng 45.
\end{abstract}

Kata kunci : kinerja, kompetensi, motivasi kerja

\begin{abstract}
The aims of this study were to obtain the proven explanatory of findings on the influence of (1) competence and work motivation of the employee's performance, (2) competence of the work motivation, (3) competence of the employee's performance, (4) work motivation of the employee's performance at PD. BPR Bank Buleleng 45. The research design in this study is causal quantitative. The subject of this research is employees of PD BPR Bank Buleleng 45 and its objects are competence, work motivation, and employee's performance. The population of this study is 51 employees, which all the employees were used as observation units, so this study as population research. Data were collected by using questionnaires, and interviews, then it's analyzed the by path analysis. The results showed a positive effect of (1) competence and work motivation of the employee's performance, (2) competence of the work motivation, (3) competence of the employee's performance, and (4) work motivation of the employee's performance PD BPR Bank Buleleng 45.
\end{abstract}

Keywords: competence, employee's performance, work motivation

\section{Pendahuluan}

Suatu organisasi bisa berkembang tidak terlepas dari sumber daya manusia (SDM) yang memiliki peranan penting untuk meningkatkan kinerja karyawan dan mencapai tujuan organisasi. Salah satu cara dalam menghadapi persaingan antar organisasi yang semakin ketat yaitu dengan memberdayakan dan menggali potensi SDM yang dimiliki karyawan suatu organisasi. SDM digunakan untuk peningkatan kontribusi yang diberikan karyawan agar, tercapainya tujuan organisasi. Hal ini dipertegas oleh Sondang dan Siagian (2008: 27) bahwa, manajemen sumber daya manusia, yang baik ditunjukan kepada peningkatan kontribusi yang diberikan para pekerja dalam organisasi agar, tercapainya tujuan organisasi. 
Sumber Daya Manusia yang dimiliki organisasi tidak akan memberikan hasil yang maksimal apabila, tidak adanya dukungan dari karyawan yang mempunyai kinerja yang optimal. Secara umum pengertian kinerja adalah hasil kerja secara kualitas dari kuantitas yang dicapai seseorang karyawan dalam melaksanakan tugas yang diberikan atasan kepadanya. Peningkatan kinerja sangat penting dilakukan oleh organisasi khususnya di bidang perbankan karena, akan berinteraksi langsung dengan calon nasabah dan memberikan pelayanan yang baik. Seperti contoh di bidang perbankan bagian BPR konvensional selalu bersaing sangat ketat dari tahun ke tahun. Perbandingan antar sesama BPR dapat dilihat dari kepemilikan aset yang dimiliki. Adapun 3 sampel BPR yang berada di Singaraja sebagai perbandingan dengan BPR lainnya mengenai kepemilikan asetnya dapat dilihat dari laporan publikasi dari tahun 2017 dan tahun 2018.

Berdasarkan tabel perbandingan BPR dilihat dari total aset yangdimilikii pada tahun 2017 dan tahun 2018. PD BPR Bank Buleleng 45 berada di peringkat terbawah dari PT BPR Indra Candra dan PT BPR Bank Kanaya. Kepemilikan aset dapat menentukan peringkat BPR. Kepemilikan aset di Bank 45 pada tahun 2017 sampai tahun 2018 mengalami penurunan. Kepemilikan aset rendah disebabkan karena, kinerja karyawan yang rendah. Perusahaan hanya menuntut kinerja karyawan tinggi, tanpa melihat faktor-faktor yang akan mempengaruhinya. Faktor-faktor yang menunjang kinerja karyawan diantaranya kompetensi dan motivasi kerja. Kompetensi sebagai salah satu cara dalam meningkatkan motivasi kerja. Kompetensi yang dimiliki karyawan harus sesuai dengan posisi pekerjaan sehingga meningkatkan kinerja karyawan. Selain kompetensi faktor motivasi termasuk faktor untuk meingkatkan kinerja.

PD BPR Bank Buleleng 45 merupakan salah satu BUMD perbankan yang berada di daerah Singaraja beralamat di jalan pramuka nomor 7 . Bank 45 termasuk perusahaan milik pemerintah Buleleng. Sejarah PD BPR Bank Buleleng 45 berawal pada tahun 1957 praaksara angkatan 45 di kota Singaraja saat itu mendirikan pasar yang diberikan status Maskai Andil Indonesia (MAI) dan diberi nama MAI Bank Pasar Angkatan 45 yang dipimpin oleh veteran pejuang kemerdekaan Indonesia dengan direksi komisaris beranggotakan \pm 100 orang angkatan 45 saat ini berubah nama menjadi PD BPR Bank Buleleng 45. PD BPR Bank Buleleng 45 memiliki peran untuk meningkatkan kesejahtraan masyarakat dengan menghimpun dana dari masyarakat dan menyalurkan kembali dana dalam bentuk kredit.

Tugas dan fungsi dari Bank 45 yaitu membantu dan mendorong pertumbuhan perekonomian khususnya serta pembangunan daerah khususnya di daerah Buleleng yang bertujuan untuk meningkatkan taraf hidup rakyat. Tugas lain PD BPR Bank Buleleng 45 yaitu menghimpun dana dari masyarakat ke dalam bentuk tabungan dan deposito, memberikan kredit ke masyarakat khususnya di Buleleng serta melakukan pembinaan-pembinaan yang khusus terhadap para pengusahan yang bergolongan lemah. Berdasarkan observasi yang dilakukan di PD BPR Bank Buleleng 45 kinerja karyawan menjadi faktor penting karena merupakan harapan dari atasan terhadap bawahannya.

Hal-hal yang dirasakan yaitu kinerja karyawan di PD BPR Bank Buleleng 45masih belum optimal yang disebabkan karena, Tingkat Pendidikan yang belum sesuai, kompetensi karyawan kurang sehingga, menyebabkan rendahnya motivasi kerja karyawan. Menurut Wibowo (2013) berpendapat bahwa bahwa, kinerja merupakan implementasi dari perancanaan yang telah disusun tersebut. Dimensi kinerja yang digunakan dalam penelitian ini adalah (1) kualitas kerja terdiri dari ketepatan waktu, ketelitian, kemampuan, dan keterampilan karyawan, (2) kuantitas kerja terdiri dari memenuhi standar kerja serta pekerjaan rutin terlaksana dengan cepat, (3) tingkat kehandalan terdiri dari inisiatif, rajin dan (4) sikap meliputi loyalitas dan tanggung jawab karyawan serta kerja sama dalam tim, sesuai dengan Husnan (2002).Indikator yang digunakan dalam penelitian ini adalah (1) hasil kerja terdiri dari kuantitas hasil kerja dan kualitas hasil kerja, efisiensi, (2) perilaku kerja terdiri dari disiplin kerja, inisiatif dan ketelitian, (3) sifat pribadi terdiri dari tiga indikator yaitu kepemimpinan, kejujuran dan kreativitas, sesuai dengan Wirawan (2009).

Implementasi kinerja dilakukan oleh sumber daya manusia yang memiliki kompetensi, motivasi dan kepentingan. Pencapaian kinerja karyawan masih rendah, dilihat dari 10 orang 
karyawan sebagai sampel.Berdasarkan tabel mengenai kuesioner awal kinerja karyawan secara total kinerja karyawan di PD BPR Bank Buleleng 45 tergolong rendah, dengan rentang skor tertinggi tertinggi 300-252 dan rentang skor terendah 153-105.Rendahnya kinerja karyawan berdasarkan fakta-fakta yang terjadi dilapangan disebabkan karena, rendahnya kompetensi karyawan. Menurut Sedarmayanti (2007) menjelaskan kompetensi adalah karakteristik mendasar yang dimiliki seseorang yang berpengaruh langsung terhadap atau yang memprediksikan prestasi kerja yang sangat baik.Dimensi-dimensi dari kompetensi yang akan digunakan dalam penelitian ini adalah menggunakan lima dimensi-dimensi kompetensi yaitu meliputi: (1) task skills yaitu keterampilan untuk melaksanakan tugas-tugas rutin sesuai dengan standar di tempat kerja, (2) task management skills yaitu keterampilan untuk mengelola serangkaian tugas berbeda yang muncul dipekerjaan, (3) contingency management skills yaitu keterampilan pengambilan tindakan yang cepat dan tepat bila, timbul suatu masalah dalam pekerjaan, (4) jole role environment skills yaitu keterampilan untuk bekerja sama serta memelihara kenyamanan lingkungan kerja. (5) Transfer skilss yaitu keterampilan untuk beradaptasi dengan lingkungan baru, sesuai dengan Moeheriono (2012).Indikator kompetensi yang digunakan dalam penelitian ini adalah (1) pengetahuan (2) kemampuan (3) keterampilan, sesuai dengan Mangkunegara (2012).

Menurut Suharsaputra (2010) yang menjelaskan bahwa faktor kemampuan/kompetensi dapat mempengaruhi kinerja karena dengan kemampuan yang tinggi, maka kinerja pegawai pun akan tercapai. Sebaliknya, apabila kemampuan pegawai rendah atau tidak sesuai dengan keahliannya, maka kinerja pun tidak akan tercapai. Pertama, mengenai pengetahuan dalam melaksanakan tugas belum maksimal. Seperti contoh pengetahuan karyawan mengenai produk-produk yang ditawarkan belum menguasai. Pengetahuan karyawan di bidang umum masih dirasakan kurang. Seperti contoh pelayanan yang diberikan masih kurang banyak halhal mengenai perusahaan yang belum diketahui dan masih menanyakan ke atasannya. Kedua, mengenai kemampuan dalam mengelola serangkaian tugas yang berbeda masih rendah. Seperti contohnya pada saat karyawan staf kredit memasukan data kredit sering terjadi kesalahan sehingga, harus di revisi berulang-ulang dan menghabiskan waktu lama dalam penyelesaian laporan keuangan, kemampuan karyawan dalam beradaptasi dengan lingkungan di tempat kerja masih kurang, kemampuan dalam memberikan pelayanan terhadap calon kreditur, kemampuan dalam melayani calon nasabah masih lambat.Ketiga, mengenai keterampilan dalam mengambil tindakan, keterampilan dalam mengidentifikasi masalahmasalah yang akan dihadapi sehingga, tidak menanyakan lagi ke atasan yang membuat waktu lama, keterampilan dalam memelihara kenyamanan lingkungan di tempat kerja. Belum direalisasikan dengan baik. Keterampilan dalam beradaptasi dengan lingkungan ditempat kerja. Seperti contoh tidak adanya tegur sapa antar karyawan yang lainnya.

Berdasarkan dari fakta-fakta yang ada dapat diperkuat dengan hasil kuesioner awal yang diberikan ke 10 orang karyawan.Berdasarkan Tabel kuesioner awal kompetensi secara total kompetensi karyawan di PD BPR Bank Buleleng 45 tergolong rendah dengan rentang skor tertinggi 300-252 dan rentang skor terendah 153-105. Fokus terhadap pendekatan kompetensi maka, berkaitan dengan aktualisasi diri untuk memenuhi kebutuhan diperlukan motivasi dari atasan terhadap bawahannya. Terdapat 3 hal yang kurang dalam pemberian motivasi yaitu arah prilaku seperti contoh prilaku karyawan dalam meningkatkan potensi masih kurang. Tingkat usaha seperti contoh belum meningkatkan prestasi kerja, tingkat kegigihan seperti contoh dalam menghadapi rintangan belum bisa menyelesaikan masalah sendiri. Berdasarkan dari fakta-fakta yang ada. Hal ini diperkuat dari hasil kuesioner awal 10 orang karyawan sebagai sampel dan wawancara langsung dengan karyawan.

Menurut Kadarisman (2012: 278) mengatakan bahwa, motivasi kerja adalah penggerak atau pendorong dalam diri seseorang untuk mau berprilaku dengan giat dan baik sesuai dengan tugas dan kewajiban yang telah diberikan kepadanya. Dimensi yang digunakan dalam penelitian ini adalah (1) tujuan karyawan bekerja dan (2) prilaku karyawan sesauai dengan Ivancevich dkk (2006). Indikator yang digunakan dalam penelitian ini yaitu meliputi: (1) arah prilaku yaitu prilaku yang dipilih seseorang untuk ditunjukan, (2) tingkat usaha yaitu menggambarkan seberapa keras seseorang bekerja (3) tingkat kegigihan yaitu prilaku 
karyawan dalam menghadapi rintangan menggambarkan usaha yang akan ditempuh seseorang untuk menyelesaikan masalah, sesuai dengan George dan Jones (2005). Dari pemaparan di atas maka dapat dirumuskan hipotesis sebagai berikut.

$\mathrm{H}_{1}$ : Ada pengaruh kompetensidan motivasi kerja terhadap kinerja karyawan di PD BPR Bank Buleleng 45.

Setiawan dan Ghozali (2006) menyatakan bahwa, kinerja merupakan fungsi dari motivasi dan kemampuan (kompetensi). Sejalan dengan teori Wibowo (2013) implementasi kinerja dilakukan oleh sumber daya manusia yang memiliki kompetensi, motivasi dan kepentingan. Hal ini, didukung oleh penelitian penelitian empirik dari Adji dan Awar (2006) bahwa, kompetensi dan motivasi kerja berpengaruh signifikan terhadap kinerja karyawan. Jadi dengan demikian dapat disimpulkan bahwa kompetensi dan motivasi kerja berpengaruh terhadap kinerja karyawan.

$\mathrm{H}_{2}$ : Ada pengaruh kompetensi terhadap motivasi kerja di PD BPR Bank Buleleng 45

Wibowo (2010) menjelaskan ada dua faktor utama yang mempengaruhi motivasi yaitu faktor pertama pegawai terdiri dari kemampuan, pengetahuan, watak dan ciri, emosi, suasana hati, keyakinan dan nilai-nilai. Faktor kedua pekerjaan meliputi lingkungan fisik, tugas yang diberikan, pendakatan organisasi terhadap pengakuan dan pengakuan superior, pengawasan, bimbingan, dan budaya organisasi. Dengan demikian motivasi prilaku secara langsung dipengaruhi pengetahuan, kemampuan dan keterampilan. Hal ini, didukung oleh penelitian empirik dari Nilam,dkk (2013) bahwa, kompetensi terhadap motivasi kerja memiliki pengaruh yang signifikan. Jadi dengan demikian dapat disimpulkan bahwa kompetensi berpengaruh terhadap motivasi kerja.

$\mathrm{H}_{3}$ : Ada pengaruh kompetensi terhadap kinerja karyawan di PD BPR Bank Buleleng 45

Suharsaputra (2010) menjelaskan bahwa faktor kemampuan/kompetensi dapat mempengaruhi kinerja karena dengan kemampuan yang tinggi, maka kinerja pegawai pun akan tercapai. Sebaliknya, apabila kemampuan pegawai rendah atau tidak sesuai dengan keahliannya, maka kinerja pun tidak akan tercapai. Sejalan teori Wibowo (2007) meyatakan kompetensi adalah suatu kemampuan untuk melaksanakan atau melakukan suatu pekerjaan yang dilandasi atas keterampilan dan pengetahuan serta didukung oleh sikap kerja yang dituntut oleh pekerjaan tersebut. Hal ini, didukung oleh penelitian empirik dari Lucia dan Agus (2014) bahwa, kompetensi berpengaruh signifikan terhadap kinerja karyawan. Jadi dengan demikian dapat disimpulkan bahwa kompetensi berpengaruh terhadap kinerja karyawan.

$\mathrm{H}_{4}$ : Ada pengaruh motivasi kerja terhadap kinerja karyawan di BPR Bank Buleleng 45

Mangkunegara (2007) yaitu terdapat hubungan antara motivasi dengan kinerja artinya pimpinan, manajer, pegawai yang mempunyai motivasi yang tinggi akan memiliki kinerja yang tinggi. Sejalan dengan teori Kasmir (2016) mengatakan jika, karyawan memiliki dorongan yang kuat dari dalam dirinya maka, karyawan akan terangsang dan terdorong dalam melakukanuntuk melakukan sesuatu. Hal ini, didukung oleh penelitian empirik dari Olivia bahwa, motivasi terhadap kinerja berpengaruh signifikan.Jadi dengan demikian dapat disimpulkan bahwa motivasi kerja berpengaruh terhadap kinerja karyawan.

Berdasarkan tabel kuesioner awal motivasi secara total motivasi karyawan di PD BPR Bank Buleleng 45 tergolong rendah dengan rentang skor tertinggi tertinggi 300-252 dan rentang skor terendah 153-105. Berdasarkan fakta-fakta masalah yang diungkapkan diatas, masalah penurunan kinerja karyawan disebabkan karena, kompetensi yang rendah dan motivasi kerja yang rendah. Menurut Setiawan dan Ghozali (2006) menyatakan bahwa, kinerja merupakan fungsi dari motivasi dan kemampuan (kompetensi). Hal ini menunjukan adanya kesenjangan teori dengan masalah yang ada dilapangan yaitu rendahnya kompetensi dan rendahnya motivasi kerja yang dimiliki karyawan di PD. BPR Bank Buleleng 45. Hal ini, didukung oleh penelitian empirik Adji dan Awar (2006) bahwa, kompetensi dan motivasi kerja berpengaruh signifikan terhadap kinerja karyawan. Berdasarkan kesenjangan fakta-fakta masalah di lapangan dengan teori yang ada maka, perlu melakukan penelitian yang dituangkan dalam judul "Pengaruh Kompetensi dan Motivasi Kerja terhadap Kinerja Karyawan di PD BPR Bank Buleleng 45".Penelitian ini dilakukan dari bulan Februari - September 2019. 
Berdasarkan latar belakang masalah maka, rumusan masalah penelitian ini, adalah sebagai berikut. (1) Bagaimana pengaruh kompetensi dan motivasi kerja terhadap kinerja karyawan di PD BPR Bank Buleleng 45? (2) Bagaimana pengaruh kompetensi terhadap motivasi kerja di PD BPR Bank Buleleng 45? (3) Bagaimana pengaruh kompetensi terhadap kinerja karyawan di PD BPR Bank Buleleng 45? dan (4) Bagaimana pengaruh motivasi kerja terhadap kinerja karyawan di PD BPR Bank Buleleng 45?

Tujuan penelitian ini adalah untuk memperoleh temuan eksplanatif yang teruji mengenai hal sebagai berikut (1) kompetensi dan motivasi kerja terhadap kinerja karyawan di PD BPR Bank Buleleng 45. (2) kompetensi terhadap kinerja karyawan di PD BPR Bank Buleleng 45. (3) motivasi kerja terhadap kinerja karyawan di PD BPR Bank Buleleng 45. (4) Kompetensi terhadap motivasi kerja karyawan di PD BPR Bank Buleleng 45.

Hasil penelitian ini diharapkan dapat memberikan manfaat berupa manfaat teoritis dan manfaat praktis. Secara teoritis penelitian ini diharapkan dapat memberikan manfaat dalam pengembangan ilmu ekonomi pada bidang manajemen sumber daya manusia mengenai kompetensi, motivasi kerja, dan kinerja, serta secara praktis hasil penelitian ini diharapkan dapat memberikan saran dan guna peningkatan kualitas sumber daya manusia bagi PD BPR Bank Buleleng 45 dalam upaya pencapaian kinerja yang optimal.

\section{Metode}

Desain penelitian yang digunakan adalah kuantitatif kausal.Penelitian kausal adalah desain penelitian yang bertujuan menentukan hubungan dan pengaruh dari suatu variabel terhadap variabel lainnya.desain kausal dapat dilakukan dengan langkah-langkah sebagai berikut: (1) merumuskan masalah, (2) kajian pustaka, (3) merumuskan hipotesis, (4) mengumpulkan data, (5) mengolah data, dan (6) menarik kesimpulan. Adapun variabel-variabel yang digunakan dalam penelitian ini adalah variabel $X_{1}$ atau variabel bebas pertama yaitu kompetensi, variabel $\mathrm{X}_{2}$ atau variabel bebas kedua yaitu motivasi kerja, dan variabel terikatnya adalah $\mathrm{Y}$ yakni kinerja karyawan.

Subjek dalam penelitian ini adalah karyawan PD. BPR Bank Buleleng 45, sedangkan objek dalam penelitian ini adalah kompetensi, motivasi kerja, dan kinerja karyawan PD. BPR Bank Buleleng 45. Populasi dalam penelitian ini adalah seluruh karyawan PD BPR Bank Buleleng 45 yang berjumlah 51 orang. Penelitian ini merupakan penelitian populasi, karena menggunakan seluruh karyawan PD BPR Bank Buleleng 45. Hal tersebut dilakukan untuk mendapatkan kesimpulan penelitian yang menggambarkan keadaan populasi sebenarnya.

Jenis data yang dikumpulkan dalam penelitian ini berupa data kompetensi, motivasi kerja, dan kinerjakaryawan yang bersumber dari PD. BPR Bank Buleleng 45. Adapun metode pengumpulan data yang digunakan dalam penelitian ini adalah (1) kuesioner, (2) pencatatan dokumen dan (2) wawancara langsung. Kuesioner dalam suatu penelitian tentu harus memenuhi syarat validitas dan reliabilitas. Dalam penelitian ini, pengujian instrumen dilakukan pada instansi agar dapat memperoleh keakuratan data. Metode analisis data dalam penelitian ini adalah dengan menggunakan analisis jalur (path analysis). Analisis jalur (path analysis) digunakan untuk mengetahui besarnya pengaruh total dan pengaruh langsung maupun tidak langsung variabel kompetensi dan motivasi kerja terhadap kinerja karyawan pada PD. BPR Bank Buleleng 45. Perhitungan analisis jalur dalam penelitian ini dibantu dengan program Statistical Package for Social Science (SPSS) 21.0 for windows. Data variabel sebelumnya menggunakan data ordinal tetapi dikarenakan pengolahan data dengan penetapan statistik parametrik mensyaratkan data sekurang-kurangnya harus diukur dalam skala interval maka perlu dilakukan transformasi ke data interval menggunakan Method of Succesive Internal (MSI) baik untuk variabel kompetensi, motivasi kerja maupun variabel kinerja pegawai.

\section{Hasil dan Pembahasan \\ Hasil}

Hasil dari analisis jalur pengaruh kompetensi dan motivasi kerja terhadap kinerja karyawan PD BPR Bank Buleleng 45 dengan bantuan aplikasi komputer Statistical Package for 
Social Sience (SPSS) 20.0 for Windows, maka diperoleh hasil penelitian seperti yang tampak pada Tabel 1 berikut ini.Tabel 1

Output SPSS Analisis Jalur Pengaruh Kompetensi $\left(\mathrm{X}_{1}\right)$ dan Motivasi Kerja $\left(\mathrm{X}_{2}\right)$ terhadap Kinerja Karyawan (Y) di PD BPR Bank Buleleng 45

\begin{tabular}{ccccc}
\hline Parameter & Koefisien & $\boldsymbol{p}$-value & Alpha $(\boldsymbol{\alpha})$ & Keputusan \\
\hline $\mathrm{Ryx}_{1} \mathrm{x}_{2}$ & 0,827 & 0,000 & 0,05 & Menolak Ho \\
$\mathrm{R}^{2} \mathrm{yx}_{1} \mathrm{x}_{2}$ & 0,685 & 0,000 & 0,05 & Menolak Ho \\
$\mathrm{Pyx}_{1}$ & 0,342 & 0,000 & 0,05 & Menolak Ho \\
$\mathrm{P}^{2} \mathrm{yx}_{1}$ & 0,117 & 0,000 & 0,05 & Menolak Ho \\
$\mathrm{Pyx}_{2}$ & 0,602 & 0,000 & 0,05 & Menolak Ho \\
$\mathrm{P}^{2} \mathrm{yx}_{2}$ & 0,362 & 0,000 & 0,05 & Menolak Ho \\
$\mathrm{Px}_{2} \mathrm{x}_{1}$ & 0,706 & 0,000 & 0,05 & Menolak Ho \\
$\mathrm{P}^{2} \mathrm{X}_{2} \mathrm{X}_{1}$ & 0,498 & 0,000 & 0,05 & Menolak Ho \\
$\mathrm{Py}_{2}$ & 0,315 & - & - & - \\
$\mathrm{Px}_{2} \varepsilon_{1}$ & 0,502 & - & - & - \\
\hline
\end{tabular}

Sumber: Pengolahan Data SPSS

Pengaruh masing-masing variabel kompetensi kerja, motivasi kerja terhadap kinerja karyawan di PD BPR Bank Buleleng 45 dapat digambarkan pada Gambar 4.1.

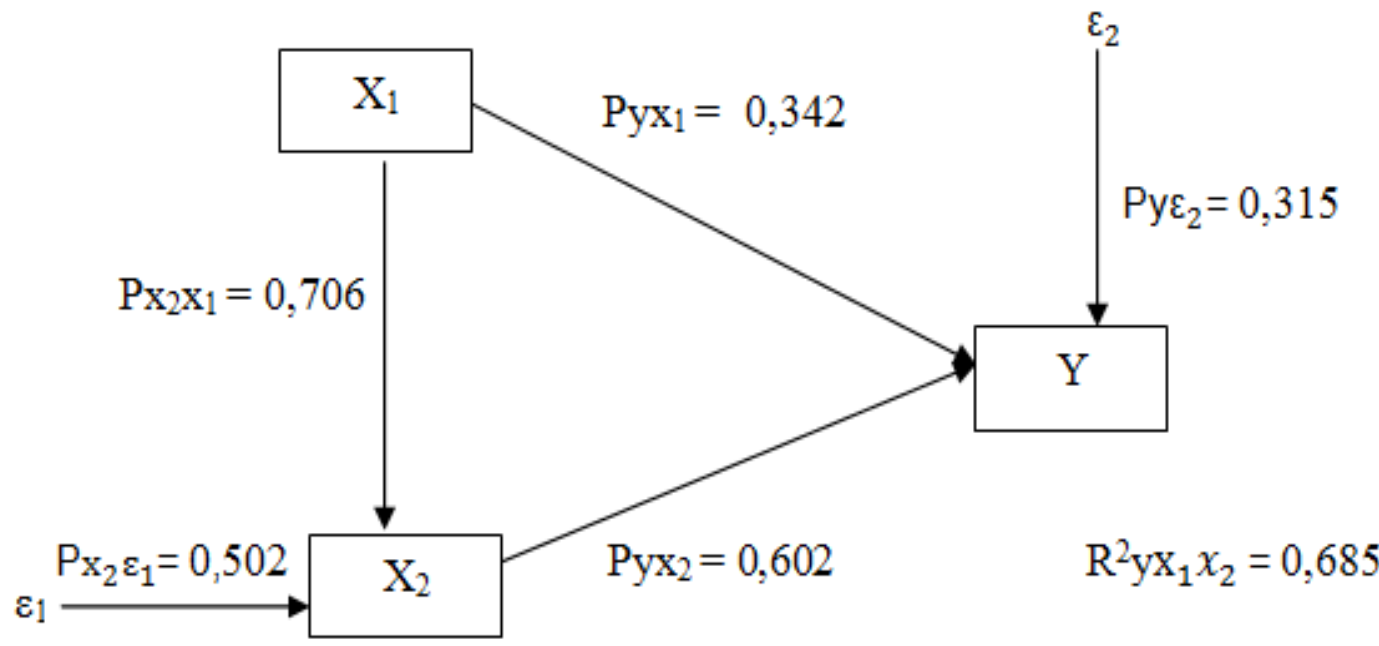

Gambar 1

Pengaruh Variabel Kompetensi $\left(\mathrm{X}_{1}\right)$ dan Motivasi Kerja $\left(\mathrm{X}_{2}\right)$ Terhadap Kinerja Karyawan (Y) di PD BPR Bank Buleleng 45.

Besar sumbangan pengaruh langsung dan tidak langsung dari $X_{1}$ dan $X_{2}$ terhadap $Y$ dalam penelitian ini dapat dilihat pada Tabel 2 .

Tabel 2

Sumbangan Pengaruh Variabel Kompetensi $\left(\mathrm{X}_{1}\right)$ dan Motivasi Kerja $\left(\mathrm{X}_{2}\right)$ Terhadap Kinerja Karyawan $(Y)$

\begin{tabular}{ccc}
\hline Keterangan & Besar Sumbangan & Persentase \\
\hline Besar pengaruh langsung $\mathrm{X}_{1}$ terhadap $\mathrm{Y}$ & 0,117 & $11,70 \%$
\end{tabular}




$\begin{array}{lcc}\begin{array}{l}\text { Besar pengaruh tidak langsung } X_{1} \text { terhadap } Y \\ \text { melalui } X_{2}\end{array} & 0,206 & 20,60 \% \\ \text { Besar pengaruh total } X_{1} \text { terhadap } Y & 0,323 & 32,30 \% \\ \text { Besar pengaruh langsung } X_{2} \text { terhadap } Y & 0,362 & 36,20 \% \\ \text { Besar pengaruh total } X_{1} \text { dan } X_{2} \text { terhadap } Y & 0,685 & 68,50 \% \\ \text { Besar pengaruh lain } X_{1} \text { dan } X_{2} \text { terhadap } Y & 0,315 & 31,50 \% \\ \text { Total } & 1,000 & 100,00 \%\end{array}$

Hipotesis penelitian yang pertama adalah "ada pengaruh kompetensi dan motivasi kerja terhadap kinerja karyawan di PD. BPR Bank Buleleng 45." Berdasarkan hasil penelitian dengan bantuan aplikasi SPSS 20.0 for windows, Diperoleh hasil $R=0,827$, dimana $p$-value untuk uji $F$ sebesar $0,00<0,05$ berarti secara simultan kompetensi dan motivasi kerja berpengaruh terhadap kinerja ini artinya Ho ditolak yang berarti ada pengaruh dari kompetensi dan motivasi kerja terhadap kinerja karyawan. Besar sumbangan pengaruh kompetensi dan motivasi kerja karyawan dipengaruhi oleh kompetensi dan motivasi kerja sebesar $68,50 \%$ sedangkan sisanya sebesar $31,50 \%$ dipengaruhi oleh variabel lain.

Hipotesis penelitian yang kedua adalah "ada pengaruh kompetensi terhadap motivasi kerja di PD. BPR Bank Buleleng 45." Berdasarkan hasil penelitian dengan bantuan aplikasi SPSS 20.0 for windows, diperoleh hasil $\mathrm{R}=0,706$ dengan nilai $\mathrm{p}$-value untuk uji $\mathrm{F}$ sebesar $0,000<0,05$. ini artinya Ho ditolak dan $\mathrm{H} 1$ diterima yang berarti ada pengaruh kompetensi terhadap motivasi kerja di PD. BPR Bank Buleleng 45. Besar sumbangan pengaruh kompetensi dan motivasi kerja karyawan dipengaruhi oleh kompetensi terhadap motivasi kerja sebesar $49,80 \%$ sedangkan sisanya sebesar $50,20 \%$ dipengaruhi oleh variabel lain.

Hipotesis yang ketiga adalah "ada pengaruh kompetensi terhadap kinerja karyawan di PD. BPR Bank Buleleng 45"diperoleh hasil $R=0,205$ dengan nilai $p$-value untuk uji $F$ sebesar $0,000<0,05$. ini artinya Ho ditolak dan $\mathrm{H} 1$ diterima yang berarti ada pengaruh kompetensi terhadap kinerja karyawan di PD. BPR Bank Buleleng 45. Besarnya sumbangan pengaruh kompetensi terhadap kinerja karyawan yaitu sebesar $11,70 \%$.

Hipotesis keempat dalam penelitian ini adalah "ada pengaruh motivasi kerja terhadap kinerja karyawan di PD. BPR Bank Buleleng 45" diperoleh hasil $\mathrm{R}=0,423$ dengan nilai $\mathrm{p}$-value untuk uji $\mathrm{F}$ sebesar $0,000<0,05$. ini artinya Ho ditolak dan $\mathrm{H} 1$ diterima yang berarti ada pengaruh terhadap kinerja karyawan di PD. BPR Bank Buleleng 45. Besarnya sumbangan pengaruh motivasi terhadap kinerja karyawan yaitu sebesar $36,20 \%$.

\section{Pembahasan}

Hasil penelitian menunjukkan bahwa variabel kompetensidan motivasi kerjasecara bersama-sama mempengaruhi kinerja karyawandi PD. BPR Bank Buleleng 45. Hasil penelitian ini sejalan dengan teori dariSetiawan dan Ghozali (2006) menyatakan bahwa, kinerja merupakan fungsi dari motivasi dan kemampuan (kompetensi). Sejalan dengan teori Wibowo (2013) implementasi kinerja dilakukan oleh sumber daya manusia yang memiliki kompetensi, motivasi dan kepentingan. Hal ini, didukung oleh penelitian penelitian empirik dari Adji dan Awar (2006) bahwa, kompetensi dan motivasi kerja berpengaruh signifikan terhadap kinerja karyawan. Jadi dengan demikian dapat disimpulkan bahwa kompetensi dan motivasi kerja berpengaruh positif terhadap kinerja karyawan.

Hasil penelitian menunjukkan bahwa kompetensiterhadap kinerja karyawan menunjukkan bahwa kompetensisecara positif berpengaruh terhadap kinerja karyawandi PD. BPR Bank Buleleng 45. Hasil penelitian ini sejalan dengan teori Suharsaputra (2010) menjelaskan bahwa faktor kemampuan/kompetensi dapat mempengaruhi kinerja karena 
dengan kemampuan yang tinggi, maka kinerja pegawai pun akan tercapai. Sebaliknya, apabila kemampuan pegawai rendah atau tidak sesuai dengan keahliannya, maka kinerja pun tidak akan tercapai. Sejalan teori Wibowo (2007) meyatakan kompetensi adalah suatu kemampuan untuk melaksanakan atau melakukan suatu pekerjaan yang dilandasi atas keterampilan dan pengetahuan serta didukung oleh sikap kerja yang dituntut oleh pekerjaan tersebut. Hal ini, didukung oleh penelitian empirik dari Lucia dan Agus (2014) bahwa, kompetensi berpengaruh signifikan terhadap kinerja karyawan. Jadi dengan demikian dapat disimpulkan bahwa kompetensi berpengaruh positif terhadap kinerja karyawan.

Hasil penelitian menunjukkan bahwa motivasi kerja terhadap kinerja karyawan, menunjukkan bahwa variabel motivasi kerja berpengaruh secara positif terhadap kinerja karyawan di PD. BPR Bank Buleleng 45. Hasil penelitian ini sejalan dengan teori Mangkunegara (2007) yaitu terdapat hubungan antara motivasi dengan kinerja artinya pimpinan, manajer, pegawai yang mempunyai motivasi yang tinggi akan memiliki kinerja yang tinggi. Sejalan dengan teori Kasmir (2016) mengatakan jika, karyawan memiliki dorongan yang kuat dari dalam dirinya maka, karyawan akan terangsang dan terdorong dalam melakukanuntuk melakukan sesuatu. Hal ini, didukung oleh penelitian empirik dari Olivia bahwa, motivasi terhadap kinerja berpengaruh signifikan.Jadi dengan demikian dapat disimpulkan motivasi kerja berpengaruh positif terhadap kinerja karyawan.

Hasil penelitian selanjutnya yang diperoleh mengenai pengaruh variabel kompetensi terhadap motivasi kerja karyawan yang menunjukkan bahwa variabel kompetensi berpengaruh secara positif terhadap motivasi kerja karyawan pada PD. BPR Bank Buleleng 45. Hasil penelitian ini sejalan dengan teoriWibowo (2010) menjelaskan ada dua faktor utama yang mempengaruhi motivasi yaitu faktor pertama pegawai terdiri dari kemampuan, pengetahuan, watak dan ciri, emosi, suasana hati, keyakinan dan nilai-nilai. Faktor kedua pekerjaan meliputi lingkungan fisik, tugas yang diberikan, pendakatan organisasi terhadap pengakuan dan pengakuan superior, pengawasan, bimbingan, dan budaya organisasi. Dengan demikian motivasi prilaku secara langsung dipengaruhi pengetahuan, kemampuan dan keterampilan. Hal ini, didukung oleh penelitian empirik dari Nilam,dkk (2013) bahwa, kompetensi terhadap motivasi kerja memiliki pengaruh yang signifikan. Jadi dengan demikian dapat disimpulkan bahwa kompetensi berpengaruh positif terhadap motivasi kerja.

Keterbatasan penelitian ini adalah jumlah populasi yang digunakan dalam penelitian ini masih sempit, sehingga diharapkan bagi peneliti lain untuk menggunakan perusahaan yang lebih besar dengan subjek penelitian yang lebih luas. Di samping itu, variabel yang diteliti masih terbatas, sehingga diharapkan juga untuk menguji variabel lain yang diduga kuat dapat mempengaruhi kinerja karyawan, seperti kompetensi, promosi jabatan, tingkat pendidikan, dan kepemimpinan

\section{Simpulan dan Saran Simpulan}

Berdasarkan hasil pengujian statistik dan hipotesis serta pembahasan, maka dapat ditarik beberapa kesimpulan sebagai berikut.(1) Kompetensi dan motivasi kerja berpengaruh positif terhadap kinerja karyawan di PD. BPR Bank Buleleng 45. (2) Kompetensi berpengaruh positif terhadap motivasi kerja di PD. BPR Bank Buleleng 45. (3) Motivasi kerja berpengaruh positif terhadap kinerja karyawan di PD. BPR Bank Buleleng 45. (4) Kompetensi berpengaruh positif terhadap motivasi kerja karyawan di PD. BPR Bank Buleleng 45.

\section{Saran}

Berdasarkan temuan hasil penelitian, pembahasan dan simpulan di atas, dapat diajukan beberapa saran sebagai berikut. (1) Bagi perusahaan, diharapkan agar lebih meningkatkan produktivitas kerja karyawan melalui kompetensi intelektual dan motivasi kerja, karena temuan penelitian membuktikan bahwa kompetensi intelektual dan motivasi kerja berpengaruh terhadap produktivitas kerja. Adapun cara agar dapat meningkatkan kinerja melalui kompetensi yaitu: (1) Merekrut karyawan sesuai dengan persyaratan jabatan yang dibutuhkan oleh perusahaan. (2) Memperhatikan kemampuan yang dimiliki karyawan dan menempatkan 
jabatan sesuai dengan kemampuan yang dimilikinya. Di samping kompetensi, variabel motivasi kerja juga perlu mendapat perhatian. Motivasi kerja dapat ditingkat dengan cara yaitu: (1) memperhatikan besar gaji yang diterima oleh karyawan agar sesuai dengan beban kerja dan upah minimum regional (UMR). (2) Perusahaan memberikan kesempatan kepada para karyawan untuk mengembangkan keterampilan dan keahlian yang di milikinya, sehingga dapat memberikan ruang kreativitas pada karyawan untuk mendorong kinerja yang optimal. Oleh karena itu, kompetensi dan motivasi kerja yang tinggi maka akan mempengaruhi kinerja karyawan dalam mencapai target yang telah ditetapkan oleh perusahaan. (2) Bagi peneliti selanjutnya yang tertarik untuk mengkaji aspek yang serupa, yaitu kompetensi, motivasi kerja serta kinerja karyawan diharapkan untuk mengembangkan penelitian ini dengan menggunakan subjek penelitian yang lebih luas. Di samping, itu juga diharapkan untuk menguji variabel lain yang diduga kuat dapat mempengaruhi kinerja kerja seperti penempatan kerja, promosi jabatan, tingkat pendidikan, dan kepemimpinan.

\section{Daftar Pustaka}

Adji, Anwar.2013.Pengaruh Kompetensi dan Motivasi Kerja Terhadap Kinerja Karyawan PT.Inti Kebun Sejahtera. Diakses 25 Januari 2018.

Ghozali, Imam. 2006. Akuntansi Prilaku: Konsep dan Kajian Empiris Prilaku Akuntan, Trans:Behavioral Accounting: Concept and Kajia nEmpirical Studies Of Accountans). Semarang: Badan Penerbit UNDIP ISBN 979-704-446-7.

George dan Jones.2005. Understanding and Managing Organizational Behavior $4^{\text {th }}$ Edition, Pearson Prentice Hall.

Husnan, Suad. 2002. Dasar-dasar Teori Portofolio dan Analisis Sekuritas Edisi Tiga. Yogyakarta: AMP YKPN.

Ivancevich, John M,dkk. 2006. Perilaku dan Manjemen Organisasi. Jakarta: PT Gelora Aksara Pratama.

Kadarisman, M. 2012. Manajemen Pengembangan Sumber Daya Manusia. Jakarta: PT. Granfindo.

Kasmir. 2016. Manajemen Sumber Daya Manusia (teori dan praktik). Depok: Raja Grafindo Persada.

Lucia. 2014. Pengaruh Tingkat Kompetensi Terhadap Kinerja Pegawai Administrasi Perkantoran. Diakses 14 Februari. 2019.

Mangkunegara.A.P. 2007. Evaluasi Kinerja SDM. Bandung: PT. Remaja Rosda Karya.

Moeheriono. 2009. Pengukuran Kinerja Berbasis Kompetensi. Bogor: Ghalia

Nilam, Susi, dan Maesaroh. 2013. Hubungan Kompetensi dan Motivasi Dengan Kinerja Dinas Sosial Wonosobo.Diakses 12 Februari 2019.

Sedarmayanti. 2007. Sumber Daya Manusia dan Produktivitas Kerja. Bandung: Mandar Maja

Sondang D, Siagian. 2002. Manajemen Sumber Daya Manusia. Jakarta: Bumi Aksara.

Suharsaputara, Uhar. 2010. Administrasi Pendidikan. Bandung: PT Refika AditamaWibowo. 2010. Manajemen Kinerja. Jakarta: PT Raja Grafido Persada. 